\title{
Comparison of artificial neural networks and harmonic analysis for sea level forecasting (Urías coastal lagoon, Mazatlán, Mexico)
}

\section{Comparación de redes neuronales artificiales y análisis armónico para el pronóstico del nivel del mar (estero de Urías, Mazatlán, México)}

\author{
Erik Molino-Minero-Re1, José Gilberto Cardoso-Mohedano², Ana Carolina Ruiz-Fernández, \\ Joan-Albert Sanchez-Cabeza ${ }^{2 *}$ \\ ${ }^{1}$ Instituto de Investigaciones en Matemáticas Aplicadas y en Sistemas, Universidad Nacional \\ Autónoma de México, Circuito Escolar S/N, 04510 México DF, México. \\ ${ }^{2}$ Departamento de Procesos Oceánicos y Costeros, Instituto de Ciencias del Mar y Limnología, \\ Universidad Nacional Autónoma de México, Circuito Exterior S/N, Ciudad Universitaria, 04510 \\ México DF, México. \\ ${ }^{3}$ Unidad Académica Mazatlán, Instituto de Ciencias del Mar y Limnología, Universidad Nacional \\ Autónoma de México, Mazatlán 82000, Sinaloa, México. \\ * Corresponding author. E-mail: jasanchez@cmarl.unam.mx
}

\begin{abstract}
Urías Estuary, a coastal lagoon in northwestern Mexico, is impacted by multiple anthropogenic stressors. Its hydrodynamics (and consequent contaminant dispersion) is mainly controlled by tidal currents. To better manage the coastal lagoon, accurate tidal-level forecasting is needed. Here we compare the predictions of sea level rise simulated by a conventional harmonic analysis, through Fourier spectral analysis, and by nonlinear autoregressive models based on artificial neural networks, both calibrated and validated using field data. Results showed that nonlinear autoregressive networks are useful to simulate the sea level over a time scale of several days ( $<10$ days), in comparison to harmonic analysis, which can be used for longer time scales ( $>10$ days). We concluded that the joint use of both methods may lead to a more robust strategy to forecast the sea level in the coastal lagoon.
\end{abstract}

Key words: sea level forecasting, artificial neural networks, harmonic analysis, coastal lagoon.

RESUMEN. El estero de Urías, una laguna costera localizada en el noroeste de México, está sometido a una gran variedad de impactos ambientales. Su hidrodinámica (y la dispersión de los contaminantes) es controlada principalmente por las corrientes de marea. El primer paso para comprender los procesos estuarinos de la laguna costera es contar con una previsión precisa de las elevaciones del nivel del mar. En el presente trabajo se comparan las predicciones del nivel del mar simuladas por un modelo tradicional de análisis armónico, a través de un análisis espectral de Fourier, con modelos autorregresivos no lineales basados en redes neuronales artificiales, ambos validados y calibrados con datos de campo. Nuestros resultados mostraron que las redes autorregresivas no lineales son útiles para simular la elevación del nivel del mar con una escala relativamente corta de tiempo ( $<10$ días $)$, mientras que el modelo basado en el análisis armónico se puede utilizar para simular escalas temporales grandes ( $>10$ días). Concluimos que el uso conjunto de ambos métodos podría conducir a una estrategia más robusta para predecir las elevaciones del nivel del mar en la laguna costera.

Palabras clave: predicción del nivel del mar, redes neuronales artificiales, análisis armónico, laguna costera.

\section{INTRODUCTION}

Globally, approximately $41 \%$ of the human population lives in coastal zones (UNDP 2005), which provide environmental services such as physical protection, water regulation, nutrient cycling, food resources, refugia for aquatic species, and recreational and cultural experiences (Costanza et al. 1997). The feasibility of these services depends largely on tidal levels; consequently, an accurate sea level forecast is important to develop adequate coastal management strategies (Makarynskyy et al. 2004).

Urías Estuary is a tropical coastal lagoon in northwestern Mexico. It shelters the port of Mazatlán, which provides

\section{INTRODUCCIÓN}

Globalmente, aproximadamente $41 \%$ de la población humana vive en zonas costeras (UNDP 2005), las cuales proporcionan servicios ambientales como protección física, regulación del agua, reciclado de nutrientes, recursos alimentarios, refugio para especies acuáticas, y experiencias recreacionales y culturales (Costanza et al. 1997). La viabilidad de estos servicios depende en gran medida de la elevación del nivel del mar; por lo tanto, es importante contar con una previsión precisa del nivel del mar para poder desarrollar estrategias adecuadas para el manejo de las zonas costeras (Makarynskyy et al. 2004). 
services for commerce, tourism, fishing, seafood processing, naval industry and petroleum transportation (INEGI 2013). The estuary also receives untreated urban wastewater from Mazatlán City, cooling water from a thermoelectric power plant, and shrimp farm discharges (Alonso-Rodríguez et al. 2000, Ochoa-Izaguirre and Soto-Jiménez 2013). Its hydrodynamics (and consequent contaminant dispersion) is mainly controlled by tidal currents (Montaño-Ley et al. 2008, Cardoso-Mohedano 2013). Thus, accurate tidal-level forecasting is important to understand many estuarine processes and to manage the port activities.

In order to develop tools for sea level forecasting, we compared two methods commonly used for time series prediction. First, we used harmonic analysis (HA) (Foreman and Henry 1989, Salas-Pérez et al. 2008): the time series was analyzed by a Fourier spectral analysis and the frequencies (constituents) were used to estimate future values. HA is a powerful and widely used technique to forecast variations in sea level, but it has the following shortcomings (Lee and Jeng 2002, Filippo et al. 2012): (i) it does not consider local variations arising from meteorological forcing, which may lead to significant forecasting errors; and (ii) it requires relatively long data series ( $\sim 1$ year) in order to estimate enough harmonics.

For the second method, we used nonlinear autoregressive (NAR) models based on artificial neural networks (ANN) (Lin et al. 1996, Haykin 1999). In this approach, one defines a dynamical model that requires a set of initial conditions, which are past values of the time series, used to predict future values. Applications of ANN for sea level forecasting have been reported by several authors (Lee and Jeng 2002, SalasPérez et al. 2008, Filippo et al. 2012, Shetty and Dwarakish 2013). Although NAR networks are versatile modeling tools, they also present drawbacks, such as their sensitivity to data quality and the need of preliminary tests to set up an adequate network. Nevertheless, once the NAR network is trained and validated, the computing effort is similar to the HA model.

\section{MATERIALS AND METHODS}

\section{Study area}

Urías Estuary $\left(23^{\circ} 11^{\prime} \mathrm{N}, 106^{\circ} 22^{\prime} \mathrm{W}\right)$ is a subtropical coastal lagoon located in the state of Sinaloa, Mexico, on the southeastern coast of the Gulf of California. It has a surface area of $18 \mathrm{~km}^{2}$ and a length of $17 \mathrm{~km}$. Water circulation is dominated by a mixed tide with an average range of about $1 \mathrm{~m}$, producing a maximum tidal velocity of $0.6 \mathrm{~m} \mathrm{~s}^{-1}$ in the navigation channel (Montaño-Ley et al. 2008). The annual average surface water temperature is $25^{\circ} \mathrm{C}$, and the maximum average annual salinity is 39 (during the dry season) and the minimum is 31.7 (during the rainy season). The average annual rainfall in the area is $0.8 \mathrm{~m}$ (Ochoa-Izaguirre 1999).
El estero de Urías es una laguna costera tropical localizada en el noroeste de México. Alberga el puerto de Mazatlán, el cual proporciona servicios para el comercio, turismo, pesca, procesamiento de productos marinos, industria naval, y transporte de petróleo (INEGI 2013). El estero también recibe las aguas residuales no tratadas de la ciudad de Mazatlán, aguas de enfriamiento de una planta termoeléctrica y las descargas de granjas camaroneras (Alonso-Rodríguez et al. 2000, Ochoa-Izaguirre y SotoJiménez 2013). Su hidrodinámica (y la consecuente dispersión de los contaminantes) está controlada principalmente por las corrientes de las mareas (Montaño-Ley et al. 2008, Cardoso-Mohedano 2013). Por lo tanto, para entender muchos de los procesos estuarinos y manejar las actividades portuarias, es importante realizar pronósticos precisos del nivel del mar.

Con el fin de desarrollar herramientas para la predicción del nivel del mar, se compararon dos métodos comúnmente empleados en la predicción de series de tiempo. Primero, se realizó un análisis armónico (HA, por sus siglas en inglés) (Foreman y Henry 1989, Salas-Pérez et al. 2008): mediante un análisis espectral de Fourier, se analiza la serie de tiempo y las frecuencias obtenidas (componentes de mareas) se usan para estimar los valores futuros. El HA es una técnica poderosa y ampliamente utilizada para predecir las variaciones del nivel del mar, pero tiene las siguientes desventajas (Lee y Jeng 2002, Filippo et al. 2012): (i) no considera variaciones locales inducidas por el forzamiento meteorológico, lo cual puede conducir a importantes errores de predicción; y (ii) requiere series de datos relativamente largas ( $\sim 1$ año) para poder estimar suficientes armónicos.

Para el segundo método usamos modelos autorregresivos no lineales (NAR, por sus siglas en inglés) basados en redes neuronales artificiales (ANN, por sus siglas en inglés) (Lin et al. 1996, Haykin 1999). En este enfoque se define un modelo dinámico que requiere un conjunto de condiciones iniciales, que son valores pasados de la serie de tiempo y se usan para predecir los valores futuros. Varios autores han documentado las aplicaciones de las ANN para la predicción del nivel del mar (Lee y Jeng 2002, Salas-Pérez et al. 2008, Filippo et al. 2012, Shetty y Dwarakish 2013). A pesar de ser herramientas de modelado versátiles, las redes NAR también presentan desventajas, tales como su sensibilidad a la calidad de los datos y la necesidad de realizar pruebas preliminares para construir una red adecuada. No obstante, una vez entrenada y validada, el esfuerzo computacional de la red NAR es similar al del modelo armónico.

\section{MATERIALES Y MÉTODOS}

\section{Área de estudio}

El estero de Urías $\left(23^{\circ} 11^{\prime} \mathrm{N}, 106^{\circ} 22^{\prime} \mathrm{W}\right)$ es una laguna costera subtropical que se localiza en el estado de Sinaloa, México, en la costa sudeste del golfo de California. Tiene una 


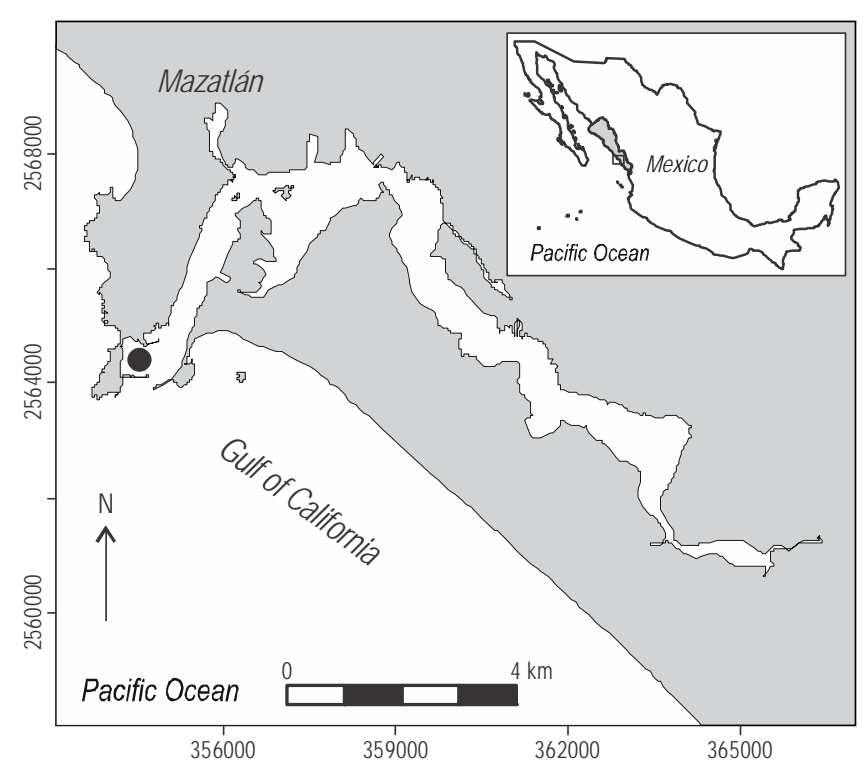

Figure 1. Urías Estuary. The sea level measurements were taken near the lagoon mouth (filled circle).

Figura 1. Estero de Urías. Las mediciones del nivel del mar se realizaron cerca de la boca de la laguna (círculo relleno).

\section{Field data}

The sea level was measured with a HOBO Titanium Water Level Data Logger (U20-001-01-Ti), located near the lagoon mouth $\left(23^{\circ} 10^{\prime} 53.15^{\prime \prime} \mathrm{N}, 106^{\circ} 25^{\prime} 25.93^{\prime \prime} \mathrm{W}\right.$; fig. 1). This and other autonomous probes have been deployed in the lagoon in order to provide long-term time series. Water column pressure data were collected every 30 min during a period of 326 days. This sampling period was considered to be adequate to capture diurnal sea level cycles and, at the same time, it allowed extending both the probe internal battery life and memory. The certified instrument uncertainty was $\pm 0.05 \%$. In order to calculate the sea level, the atmospheric pressure was subtracted. Finally, the tidal elevation was referred to mean sea level.

\section{Harmonic analysis}

HA refers to the study of waves and their superposition. This method is applied in many areas, such as in oceanography, to perform signal analysis (Foreman and Henry 1989, Pawlowicz et al. 2002, Leffler and Jay 2009), as it provides a tool to divide complex signals into simple components that can be easily analyzed.

Based on Fourier series and transforms theory, a periodic signal can be represented as the sum of sinusoidal functions with different frequencies:

$$
f(t)=A_{0}+\sum_{k=1}^{\infty}\left(A_{k} \cos \omega_{k} t+\theta_{k}\right)
$$

superficie de $18 \mathrm{~km}^{2}$ y una longitud de $17 \mathrm{~km}$. La circulación del agua está dominada por una marea mixta con un intervalo promedio de $1 \mathrm{~m}$, generando una velocidad máxima de la marea de $0.6 \mathrm{~m} \mathrm{~s}^{-1}$ en el canal de navegación (Montaño-Ley et al. 2008). La temperatura promedio anual del agua superficial es de $25^{\circ} \mathrm{C}$, y la salinidad promedio es máxima (39) durante la temporada seca y mínima (31.7) durante la temporada de lluvias. La precipitación anual promedio en la zona es $0.8 \mathrm{~m}$ (Ochoa-Izaguirre 1999).

\section{Datos de campo}

La elevación del nivel del mar se midió con una sonda HOBO de titanio (U20-001-01-Ti), ubicada cerca de la boca de la laguna $\left(23^{\circ} 10^{\prime} 53.15^{\prime \prime} \mathrm{N}, 106^{\circ} 25^{\prime} 25.93^{\prime \prime} \mathrm{W}\right.$; fig. 1). Esta y otras sondas autónomas han sido instaladas en la laguna para obtener series de tiempo largas. Se registraron datos de la presión de la columna de agua cada 30 min durante un periodo de 326 días. Este periodo de muestreo fue considerado adecuado para capturar los ciclos diurnos del nivel del mar y, a la vez, permitió extender la vida y memoria de la batería interna de la sonda. La incertidumbre del instrumento certificado fue $\pm 0.05 \%$. Para calcular el nivel del mar, se restó la presión atmosférica. Finalmente, la elevación de la marea fue referida al nivel medio del mar.

\section{Análisis armónico}

El HA se refiere al estudio de las ondas y su superposición. Es un método empleado en varias áreas, como la oceanografía, para analizar señales (Foreman y Henry 1989, Pawlowicz et al. 2002, Leffler y Jay 2009), ya que permite dividir señales complejas en componentes simples que pueden ser analizados fácilmente.

Con base en la teoria de series y transformadas de Fourier, una señal periódica puede representarse a través de la suma de funciones sinusoidales de distintas frecuencias:

$$
f(t)=A_{0}+\sum_{k=1}^{\infty}\left(A_{k} \cos \omega_{k} t+\theta_{k}\right)
$$

donde la componente sinusoidal a una frecuencia angular, $\omega_{k}=k \omega_{0}$, es el $k$-ésimo armónico de la función $f(t)$ y $t$ es el tiempo. El primer armónico de la serie es la componente fundamental de $f(t)$, con una frecuencia angular de $\omega_{0}=2 \pi f_{0}=$ $2 \pi / T \mathrm{rad} \mathrm{s}^{-1}$, donde $T$ es el periodo fundamental y $f_{0}$ es la frecuencia fundamental (en $\mathrm{Hz}$ ). Los coeficientes $A_{k}$ y $\theta_{k}$ son la $k$-ésima amplitud armónica y el $k$-ésimo ángulo de fase, respectivamente, y $A_{0}$ es una constante.

Para la estimación de las amplitudes y fases armónicas, se requiere aplicar una transformada de Fourier, usualmente mediante la transformada rápida de Fourier (Cooley y Tukey 1965). Los componentes armónicos son los de mayor intensidad, y son relativamente fáciles de identificar al graficar 
where the sinusoidal component at the angular frequency, $\omega_{k}=k \omega_{0}$, is the $k$ th harmonic of the function $f(t)$ and $t$ is the time. The first harmonic of the series is the fundamental component of $f(t)$, with an angular frequency of $\omega_{0}=2 \pi f_{0}=2 \pi / T$ $\left(\mathrm{rad} \mathrm{s}^{-1}\right)$, where $T$ is the fundamental period and $f_{0}$ is the fundamental frequency (in Hz). Coefficients $A_{k}$ and $\theta_{k}$ are the $k$ th harmonic amplitude and $k$ th phase angle, respectively, with $A_{0}$ as a constant.

To estimate the harmonic amplitudes and phases, a Fourier transform needs to be applied, usually through the fast Fourier transform algorithm (Cooley and Tukey 1965). Harmonic components are those with the highest signal intensity and are relatively easy to identify by plotting the transformed series in the frequency domain, commonly as a power spectrum and phase plot. It is worth mentioning that this spectral analysis shows the frequency content of the series with no information of the time line of the events. Consequently, the estimated frequencies are an average value of the frequencies along the whole time period analyzed and the prediction is also an average representation.

In this work, the mean tidal elevation was calculated $\left(A_{0}\right.$ amplitude) and subtracted from the data. Then, a fast Fourier transform was performed with MATLAB. The transformed series was plotted in magnitude and phase, and the main harmonics were estimated and used to build the HA model.

\section{Artificial neural networks}

ANN are powerful tools for signal analysis and system modeling (Bishop 1994, Haykin 1999). They are universal approximators that learn from data, and their nonlinear nature allows them to adapt to nonlinear functions that are difficult or impossible to express mathematically. In this work, we used ANN to forecast values of a time series by analyzing past observations. To accomplish this, NAR networks were used (Lin et al. 1996). NAR networks can be implemented under different configurations, depending on the time series problem. We implemented a simple NAR model that only uses past values of the series, $y(t)$, to forecast future values:

$$
y(t)=f(y(t-1), y(t-2), \ldots, y(t-d))
$$

where $d$ is a time-delay parameter that defines the number of past samples, and the function $f(\cdot)$ is the forecasting NAR model.

The inner structure of the NAR network is divided into layers (fig. 2). The first layer defines the delay line, that is, the number of past samples used in the model, which are connected to the input layer. Each neuron has $p$ inputs with an associated weight parameter, $w$, plus a bias weight input, $b$. Also, in each neuron there is an activation function, $g\left(u_{k}\right)$, that acts on the sums of the weight parameters and the inputs, $u_{k}=b_{k} \sum_{i}^{p}\left(w_{i, k} \cdot v_{i}\right)$, where $k$ is the number of the neuron in the hidden layer; $g$ is a nonlinear function in the case of the la serie transformada en el dominio de la frecuencia, comúnmente a través del espectro de potencia y de la fase. Cabe mencionar que este análisis espectral muestra el contenido de frecuencia de la serie sin ninguna información de la línea de tiempo. Por lo tanto, las frecuencias estimadas son un valor promedio de las frecuencias a lo largo del periodo analizado y la predicción también es una representación promedio.

En el presente trabajo, se calculó la altura promedio de la marea (amplitud $A_{0}$ ) y se restó de los datos. Posteriormente se aplicó una transformada rápida de Fourier con MATLAB. Se graficó la magnitud y fase de la serie transformada, y los armónicos principales fueron estimados y usados para construir el modelo de HA.

\section{Redes neuronales artificiales}

Las ANN son herramientas poderosas para el análisis de señales y la modelación de sistemas (Bishop 1994, Haykin 1999). Son aproximadores universales que aprenden de los datos, y su naturaleza no lineal les permite adaptar a funciones no lineales que son difíciles (o imposible) de expresar matemáticamente. En el presente trabajo se usaron ANN para predecir los valores de una serie de tiempo mediante el análisis de observaciones previas. Para realizar esto, se usó una red tipo NAR (Lin et al. 1996). Las redes NAR se pueden implementar bajo diferentes configuraciones, según el problema de la serie de tiempo. Nosotros implementamos un modelo NAR simple que sólo usa valores pasados de la serie, $y(t)$, para predecir los valores futuros:

$$
y(t)=f(y(t-1), y(t-2), \ldots, y(t-d))
$$

donde $d$ es un parámetro de retardo que define el número de muestras previas y la función $f(\cdot)$ es el modelo predictivo NAR.

La estructura interna de la red NAR se divide en capas (fig. 2). La primera capa define la línea de retardo, esto es, el número de muestras anteriores usadas en el modelo, las cuales están ligadas a la capa de entrada. Cada neurona tiene $p$ entradas asociadas a un parámetro de pesos, $w$, más el sesgo, $b$. Asimismo, cada neurona tiene una función de activación, $g\left(u_{k}\right)$, que actúa sobre las sumas de las entradas y los parámetros de peso, $u_{k}=b_{k} \sum_{i}^{p}\left(w_{i, k} \cdot v_{i}\right)$, donde $k$ es el número de la neurona en la capa oculta; $g$ es una función no lineal en el caso de las neuronas de la capa oculta, $g\left(u_{k}\right)=$ $\tan h\left(u_{k}\right)$, y es una función lineal en el caso de la neurona de salida, $g\left(u_{k}\right)=u_{k}$.

Se ha mostrado que, debido a las funciones no lineales usadas en las capas internas, las redes neuronales tienen una capacidad de aproximación universal, y si se dispone de un suficiente número de neuronas, la red puede representar cualquier mapa continuo (Bishop 1994); sin embargo, para reducir el esfuerzo de computo, se recomienda usar el menor 


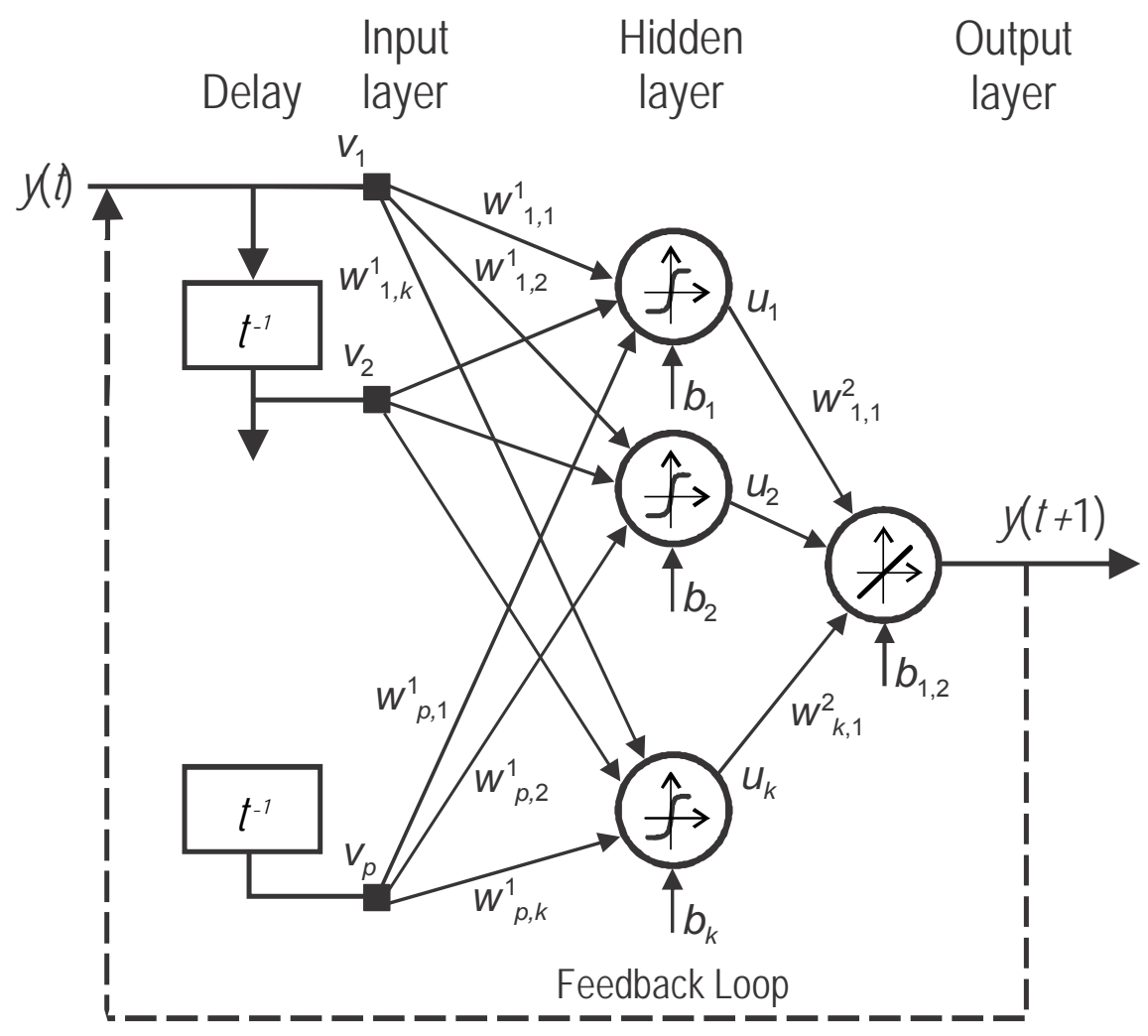

Figure 2. Nonlinear autoregressive network architecture. Feedback loop is open for training and closed for predictions.

Figura 2. Arquitectura de la red autorregresiva no lineal. El bucle de retroalimentación está abierto para entrenar y cerrado para predicciones.

hidden layer neurons, $g\left(u_{k}\right)=\tan h\left(u_{k}\right)$, and it is a linear function in the case of the output neuron, $g\left(u_{k}\right)=u_{k}$.

It has been shown that, due to the nonlinear functions used in the inner layers, neural networks have a universal approximation capacity, and if sufficient neurons are available, the network is able to represent any continuous map (Bishop 1994); however, to reduce computing resources, it is preferable to use the minimum size that provides a satisfactory solution. Experience and preliminary tests are important to design the proper architecture (Haykin 1999). Furthermore, it is also necessary to define both the training data, which should be representative of the whole process, and the training process. A fraction of the dataset can be used for validation.

Training is a cyclic process, where internal weights $w$ and $b$ are modified following a rule that makes the network behave in a specific manner. The rule considers an error signal that is generated by the difference between the actual output of the network and the expected output (i.e., the desired signal). In the case of the NAR network, the set-up consists in training with the feedback loop open (no feedback) and comparing the output $y(t+1)$ with the same training signal with a shift. Once the error reaches a certain minimum value the training process ends. With the trained network, it is possible to forecast multiple future values by tamaño que proporcione una solución satisfactoria. Pruebas preliminares y la experiencia son importantes para diseñar la arquitectura apropiada (Haykin 1999). También es necesario definir los datos de entrenamiento, los cuales deberían ser representativos de todo el proceso, así como el proceso de entrenamiento. Se puede usar una fracción del conjunto de datos para la validación.

El entrenamiento es un proceso cíclico, donde se modifican los pesos internos $w$ y $b$ según una regla que hace que la red se comporte de una manera específica. La regla considera una señal de error que se genera por la diferencia entre la salida actual de la red y la salida esperada (i.e., la señal deseada). En el caso de una red NAR, el proceso consiste en entrenar con el bucle de retroalimentación abierto (sin retroalimentación) y comparar la salida $y(t+1)$ con la misma señal de entrenamiento con un corrimiento. El proceso de entrenamiento finaliza cuando el error alcanza un cierto valor mínimo. Con una red entrenada, es posible predecir múltiples valores futuros cerrando el bucle y dejando que la red se retroalimente con sus propias predicciones.

En este estudio se probaron cuatro configuraciones. El número de retardos de tiempo (TD) en la capa de entrada y el número de capas ocultas se describen en la tabla 1 . Todas las redes tuvieron una capa oculta, excepto NAR1, que tuvo dos capas ocultas para probar una arquitectura diferente: la primera capa con diez neuronas y la segunda con una. 
closing the loop, allowing the network to feed back its own predictions.

In this work four different network configurations were tested. The input time-delay layer (TD) and the number of hidden neurons are described in table 1 . All networks had one hidden layer, except NAR1, which had two hidden layers to test a different architecture: the first layer with ten neurons and the second with one neuron.

The NAR networks were implemented by using the NARNET function in MATLAB. In contrast with HA, other studies have shown that by training ANN with two to three months of field data, good forecasting results can be obtained (Lee 2004, Shetty and Dwarakish 2013). We used only 8000 samples (166.6 days) to work on the NAR networks, which are nearly half the available field data $(15,648$ samples in 326 days). Data were split into two groups, one was used for training ( $70 \%$ of the data, 5600 samples), and the other (30\% of the data) for validation. No data preprocessing was performed.

\section{RESULTS}

\section{Harmonic analysis}

The HA performed on the 326 days of field sea level data provided the harmonic constituents M2, S2, N2, K2, K1, O1, P1, and Q1 (Foreman and Henry 1989) (table 2). For a 10-day window, the best match of HA forecasted and field data were plotted in the time domain (fig. 3a), together with their difference (error). Under this condition, a good correlation, $r=0.9161$, was observed (fig. $3 \mathrm{~b}$ ). When performing a 72-day forecast, the correlation was $r=0.8918$, smaller but still close to the 10-day test.

\section{Nonlinear autoregressive networks}

Four NAR networks were used to forecast future values of sea level. In all cases, they were able to predict future values each half-hour for at least 10 days before missing stability. The forecasted and field data were plotted in the time domain, together with the corresponding error (fig. 4a, c, e, g). In addition, a cross-plot between forecasted and field data and the correlation coefficient is shown for each case (fig. 4b, $d, f, h)$.
Las redes NAR se implementaron con la función NARNET de MATLAB. En contraste con HA, otros estudios han mostrado que se pueden obtener buenos resultados de predicción si se entrenan las ANN con dos o tres meses de datos de campo (Lee 2004, Shetty y Dwarakish 2013). Nosotros usamos sólo 8000 muestras (166.6 días) para trabajar con las redes NAR, casi la mitad de los datos de campo disponibles (15,648 muestras en 326 días). Los datos fueron divididos en dos grupos. Un grupo ( $70 \%$ de los datos, 5600 muestras) se usó para el entrenamiento y el otro $(30 \%$ de los datos) se usó para la validación. No se realizó ningún tipo de preprocesamiento de los datos.

\section{RESUlTADOS}

\section{Análisis armónico}

El HA realizado para los 326 días de datos de campo de nivel del mar proporcionó los componentes armónicos M2, S2, N2, K2, K1, O1, P1 y Q1 (Foreman y Henry 1989) (tabla 2). Para un periodo de 10 días, los datos pronosticados por el HA y los datos de campo que mejor se ajustaron se graficaron en el dominio del tiempo (fig. 3a), junto con su diferencia (error), observándose una buena correlación, $r=0.9161$ (fig. 3b). Para una predicción de 72 días, la correlación fue de $r=0.8918$, menor pero cercana a la prueba de 10 días.

\section{Redes autorregresivas no lineales}

Cuatro redes NAR fueron utilizadas para predecir valores futuros del nivel del mar, y en todos los casos pronosticaron valores futuros cada media hora durante al menos 10 días antes de perder la estabilidad. Se graficaron los datos pronosticados y los datos de campo en el dominio del tiempo, junto con su error correspondiente (fig. 4a, c, e, g). También se presenta una gráfica de dispersión de los datos pronosticados y de campo, así como el coeficiente de correlación para cada caso (fig. $4 b, \mathrm{~d}, \mathrm{f}, \mathrm{h}$ ).

Los resultados muestran diferencias en el comportamiento de cada configuración. El mejor resultado se obtuvo con NAR2 ( $r=0.9707$; fig. 4c, d), que tenía una capa oculta con 20 neuronas y un retardo de 400 muestras. Su gráfica de

Table 1. Configuration of the nonlinear autoregressive (NAR) networks.

Tabla 1. Configuración de las redes autorregresivas no lineales (NAR).

\begin{tabular}{cccc}
\hline Network & Input delay* & Number of hidden layers (number of neurons) & Number of output layers \\
\hline NAR1 & $\mathrm{TD}=300$ & $2(10,1)$ & 1 \\
NAR2 & $\mathrm{TD}=400$ & $1(20)$ & 1 \\
NAR3 & $\mathrm{TD}=500$ & $1(20)$ & 1 \\
NAR4 & $\mathrm{TD}=300$ & $1(30)$ & 1 \\
\hline
\end{tabular}

* TD, size of time delay. 
Table 2. Estimated harmonic constituents for Urías Estuary.

Tabla 2. Componentes armónicos estimados para el estero de Urías.

\begin{tabular}{|c|c|c|c|c|}
\hline Harmonic & Amplitude (m) & Period (h) & Phase & Description \\
\hline M2 & 0.3145 & 12.4121 & 89.08 & Principal lunar semidiurnal constituent \\
\hline $\mathrm{S} 2$ & 0.2195 & 11.9941 & 62.55 & Principal solar semidiurnal constituent \\
\hline $\mathrm{N} 2$ & 0.0712 & 12.6615 & 159.05 & Larger lunar elliptic semidiurnal constituent \\
\hline $\mathrm{K} 2$ & 0.0581 & 11.9591 & 211.77 & Luni-solar semidiurnal constituent \\
\hline $\mathrm{K} 1$ & 0.1373 & 23.9532 & 320.07 & Luni-solar diurnal constituent \\
\hline O1 & 0.0979 & 25.8423 & 158.86 & Principal lunar diurnal constituent \\
\hline $\mathrm{P} 1$ & 0.0505 & 24.0941 & 154.20 & Principal solar diurnal constituent \\
\hline Q1 & 0.0216 & 26.8590 & 58.28 & Larger lunar elliptic diurnal constituent \\
\hline
\end{tabular}
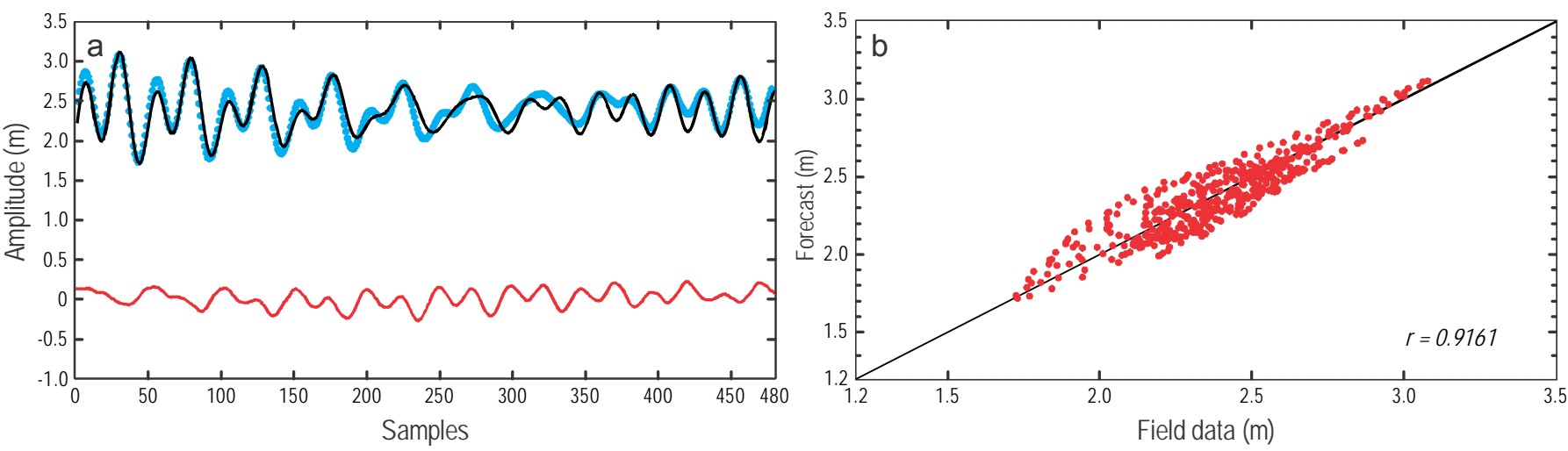

Figure 3. Harmonic analysis (HA) results using estimated amplitudes and phases. (a) HA model data (black line), field data (blue dots), and residual (red line). (b) Cross-plot (field data $v s$ HA forecast).

Figura 3. Resultados del análisis armónico con amplitudes y fases estimadas. (a) Datos del modelo armónico (línea negra), datos de campo (puntos azules) y residual (línea roja). (b) Gráfica de dispersión (datos de campo vs predicciones del modelo).

The results showed differences in the performance of each NAR configuration. The best result was achieved with NAR2 ( $r=0.9707$; fig. $4 \mathrm{c}, \mathrm{d})$. This network had one hidden layer with 20 neurons and a time delay of 400 samples. The cross-plot shows that data are well spread and close to the diagonal line, indicating a good match between the field sea level data and the forecasted data. The second best result was obtained with NAR1, which had two hidden layers, one with 10 neurons and the other with one neuron, and a time delay of 300 samples. Its performance was similar to that of NAR2 $(r=0.9623$; fig. 4a, c). NAR3 (fig. 4e, f) had one hidden layer with 10 neurons and a time delay of 500 samples, and showed a reduced performance compared with the previous networks $(r=0.9030)$, as observed in the larger dispersion of the cross-plot and the larger error of the time-domain plot. NAR4, with one hidden layer of 30 neurons and a time delay of 300 samples, showed the poorest performance $(r=0.3033$; fig. $4 \mathrm{~g}, \mathrm{~h})$. The cross-plot also shows a large dispersion. In order to compare the NAR networks with HA, a longer 72-day forecast was performed, which resulted in significantly smaller correlations of $0.3971,0.1801,0.03$, and -0.07 for NAR1, NAR2, NAR3, and NAR4, respectively. dispersión muestra que los datos están bien distribuidos y cerca de la línea diagonal, lo que indica un buen ajuste entre los datos del nivel del mar pronosticados y de campo. El segundo mejor resultado se obtuvo con NAR1, que tenía dos capas ocultas, una con 10 neuronas y la otra con una neurona, y un retardo de 300 muestras. Su desempeño fue similar al de NAR2 $(r=0.9623$; fig. 4a, c). El desempeño de NAR3, con una capa oculta con 10 neuronas y un retardo de 500 muestras, fue menor que el de NAR1 y NAR2 $(r=0.9030)$, como lo indica el mayor error (fig. 4e) y la mayor dispersión de los datos (fig. 4f). NAR4, con una capa oculta con 30 neuronas y un retardo de 300 muestras, presentó el desempeño más pobre ( $r=0.3033$; fig. $4 \mathrm{~g}, \mathrm{~h})$, observándose una gran dispersión de los datos. Para comparar las redes NAR con HA, se realizó un pronóstico para un periodo más largo de 72 días, el cual arrojó correlaciones significativamente menores de 0.3971, 0.1801, 0.03 y -0.07 para NAR1, NAR2, NAR3 y NAR4, respectivamente.

Lo anterior muestra que diferentes configuraciones pueden proporcionar resultados diferentes. El incrementar el tamaño de las redes (número de neuronas, retardos y/o capas ocultas) no necesariamente aumenta el desempeño. Para 

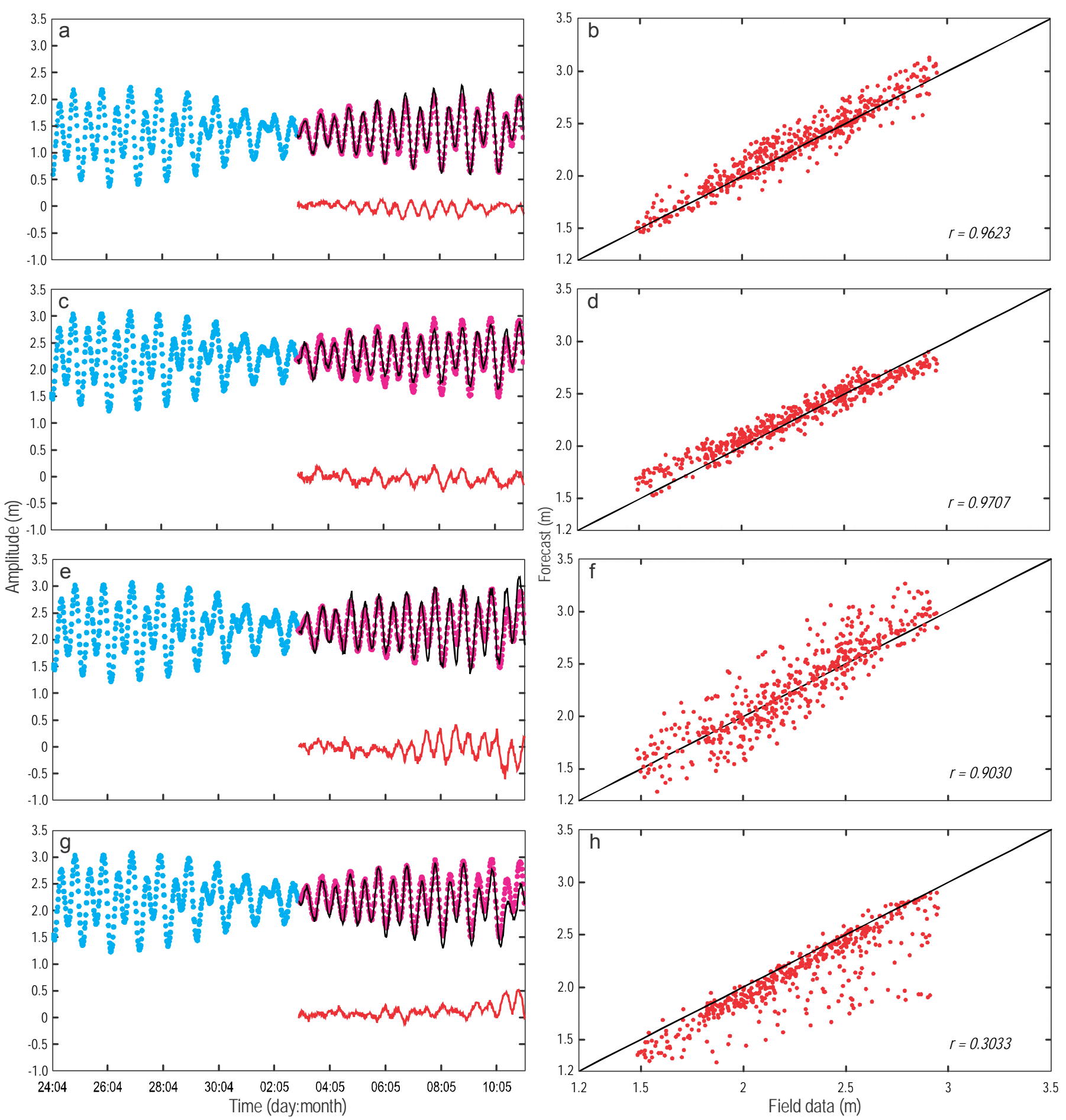

Figure 4. Nonlinear autoregressive (NAR) network forecasting results: (a, b) NAR1, (c, d) NAR2, (e, f) NAR3, and (g, h) NAR4. Left plots: forecasted data (black line), training data (blue dots), validation data (pink dots), and residual (red line). Right plots: cross-plot (field data $v s$ NAR forecast).

Figura 4. Resultados predictivos de las redes autorregresivas no lineales (NAR): (a, b) NAR1, (c, d) NAR2, (e, f) NAR3 y (g, h) NAR4. Gráficas del lado izquierdo: datos pronosticados (línea negra), datos de entrenamiento (puntos azules), datos de validación (puntos de color rosa) y residual (línea roja). Lado derecho: gráficas de dispersión (datos de campo vs predicción de las redes). 
These findings show that different configurations can provide different results. Increasing the size of the network (number of neurons, time delays, and/or hidden layers) does not necessarily increase performance. Choosing the right training data and network retraining are necessary to find an appropriate performance. Although this process is timeconsuming, neural networks learn from the data and adapt their behavior to complex phenomena.

\section{DiscuSsion}

The prediction of sea level in coastal lagoons is important for a number of socio-economic activities. In this work, we used two approaches: the conventional HA and the ANN analysis, based on NAR networks. Unprocessed field data from the Urías Estuary (Mexico) were used to evaluate both models. Our results showed important differences between the two methods.

As a general observation, HA uses the average frequency and amplitudes of the series during the period of study and no previous knowledge (initial conditions) is required. The model is stable for long time periods and if enough harmonics are identified and used in the model, it is suitable for predicting values on long time scales. Nevertheless, HA cannot model local distortions, such as those originated by meteorological forcing. The water circulation in Urías Estuary is mostly driven by the Gulf of California tides, which are mainly co-oscillations of the Pacific Ocean tides (Carbajal and Backhaus 1998). Its tidal regimen is mixed semidiurnal (Hendershott and Speranza 1971, Filloux 1973), with M2, S2, K1, O1, N2, K2, and P1 tidal harmonics (Carbajal 1993). In this work, we also found Q1.

In the case of NAR networks, as they adapt to the training data, they represent the general nature of the process. Also, NAR networks are dynamical models that require initial conditions and feedback (past values to predict future ones). This is possible because the output is fed back to the input to make multiple-step forecasts. Consequently, the forecast is in good agreement with the field data, but just for a relatively short period of time (about 10 days in this case), after which the model loses stability. This arises because after a period of forecasted values, which have inherent prediction error, these are fed back to the input and used to predict new values, leading to larger errors that eventually produce prediction instabilities.

In this work, different NAR network configurations were tested by varying the size of the time delay, the number of hidden layers, and the number of neurons. The best configuration, for a 10-day forecast, was found to have a time delay of 400 samples and one hidden layer with 20 neurons; in this case, the correlation coefficient was $r=0.9707$. The harmonic model was derived from field data and the main constituents (M2, S2, N2, K2, K1, O1, P1, and Q1) were estimated. For a 10-day forecast, the best match between the HA data and the field data had a correlation coefficient of obtener un desempeño adecuado es necesario seleccionar los datos de entrenamiento correctos y reentrenar la red. Aunque este proceso requiere tiempo, las redes neuronales aprenden de los datos y adaptan su comportamiento a fenómenos complejos.

\section{DISCUSIÓN}

La predicción del nivel del mar en lagunas costeras es importante para varias actividades socioeconómicas. En el presente trabajo se usaron dos enfoques: el HA convencional y un análisis de ANN, con base en redes NAR. Se usaron datos de campo no procesados del estero de Urías (México) para evaluar ambos modelos y los resultados arrojaron diferencias importantes entre los dos métodos.

En general, HA utiliza la frecuencia y amplitudes promedio de la serie durante el periodo de estudio y no se requiere de un conocimiento previo (condiciones iniciales). El modelo es estable para periodos largos, y si se identifican y usan suficientes armónicos, es apropiado para predecir valores en grandes escalas temporales. No obstante, el HA no puede modelar distorciones locales, como las generadas por forzamiento meteorológico. La circulación del agua en el estero de Urías es principalmente impulsada por la marea del golfo de California, que se produce generalmente por cooscilación con la marea del océano Pacífico (Carbajal y Backhaus 1998). Su régimen de marea es del tipo mixto semidiurno (Hendershott y Speranza 1971, Filloux 1973), con los armónicos M2, S2, K1, O1, N2, K2 y P1 (Carbajal 1993). En el presente estudio también se encontró Q1.

Las redes NAR, por su parte, como se adaptan a los datos de entrenamiento, representan la naturaleza general del proceso. Además, son modelos dinámicos que requieren condiciones iniciales y retroalimentación (valores previos para predecir valores futuros). Esto es posible ya que la salida se redirige a la entrada para realizar predicciones múltiples. En consecuencia, la predicción se ajusta bien a los datos de campo pero sólo durante un periodo corto de tiempo (alrededor de 10 días en este caso), después del cual el modelo pierde estabilidad. Esto sucede porque después de un periodo, los datos pronosticados, con error de predicción inherente, son redirigidos a la entrada y usados para predecir valores nuevos, y se generan errores más grandes y eventualmente predicciones inestables.

En el presente trabajo, para probar diferentes configuraciones de las redes NAR, se varió el tamaño del número de retardos de tiempo, el número de capas ocultas y el número de neuronas. La mejor configuración para una predicción de 10 días tenía un retardo de 400 muestras y una capa oculta con 20 neuronas; en este caso, el coeficiente de correlación fue $r=0.9707$. El modelo armónico se derivó de datos de campo y se estimaron los principales componentes (M2, S2, N2, K2, K1, O1, P1 y Q1). Para una predicción de 10 días, la mejor correlación entre los datos del HA y los datos de campo fue $r=0.9161$. En comparación con el HA, la red 
$r=0.9161$. In contrast to HA, the NAR network showed a better agreement with field data for the same period of time. For the long-term forecast (72 days), HA showed a better performance, with $r=0.8918$, while the NAR networks reflected the instabilities that arise due to the aforementioned errors.

With these results, it may be possible to optimize the use of both methods for forecasting different time scales, (i) using NAR networks to forecast 10 days based on field data collected from an on-line system, and (ii) using the HA model to forecast larger time windows.

In summary, the harmonic model provides average predictions, whereas the NAR network provides predictions based on specific initial conditions, which can be used to specify a starting forecast date. Likewise, because neural networks learn from the training data, they can reproduce local variations not captured by HA. The use of more complex NAR networks (more complex structure, more neurons, and larger delays) does not necessarily improve the forecasting performance, so different configurations need to be evaluated in order to find the most suitable one. Training is a key process and repletion is needed to find a suitable configuration. Both methods perform well and show advantages and disadvantages. We therefore conclude that the joint use of both methods, taking advantage of the best features of each one, may lead to a more robust strategy to forecast the sea level in Urías Estuary and other tropical coastal lagoons.

\section{ACKNOWLEDGMENTS}

JGCM and EMMR thank the National Council for Science and Technology (CONACYT, Mexico) for financial support through a postdoctoral fellowship. Partial funding was provided by the following projects: CONACYT 108093 , CB2010/153492, and INFR-2013-01 204818; PAPIITDGAPA IN203313, and IB201612; and SEP PROMEP/ 103.5/12/4812. We thank the Dirección General de Cómputo y de Tecnologías de Información y Comunicación of the National Autonomous University of Mexico (UNAM) for the use of the Miztli Cluster, where simulations were performed. We also thank Germán Ramírez Reséndiz (data management), Onésimo López Ramos (data logging), and Paola Rodríguez Reynaga (language usage and editing service).

\section{REFERENCES}

Alonso-Rodríguez R, Páez-Osuna F, Cortés-Altamirano R. 2000. Trophic conditions and stoichiometric nutrient balance in subtropical waters influenced by municipal sewage effluents in Mazatlán Bay (SE Gulf of California). Mar. Pollut. Bull. 40: 331-339. http://dx.doi.org/10.1016/S0025-326X(99)00225-8

Bishop CM. 1994. Neural networks and their applications. Rev. Sci. Instrum. 65: 1803-1832. http://dx.doi.org/10.1063/1.1144830

Carbajal N. 1993. Modelling of the circulation in the Gulf of California. Ber. Zent. Meeres- Klimaforsch. Univ. Hamb. (B Ozeanogr.) 3.
NAR presentó una mejor correlación con los datos de campo para el mismo periodo. Para un periodo más largo de 72 días, el HA presentó un mejor desempeño, con $r=0.8918$, mientras que las redes NAR reflejaron las inestabilidades que resultan de los errores antes mencionados.

Estos resultados muestran que es posible optimizar el uso de ambos métodos para las predicciones a diferentes escalas, mediante (i) el uso de las redes NAR para los pronósticos de 10 días con base en datos de campo recogidos de un sistema en línea, y (ii) el uso de un modelo armónico para los pronósticos a mayor escala de tiempo.

En resumen, el modelo armónico proporciona predicciones promedio, mientras que las redes NAR proporcionan predicciones basadas en condiciones iniciales específicas que se pueden usar para especificar una fecha inicial de predicción. Además, como las redes neuronales aprenden de los datos de entrenamiento, pueden reproducir variaciones locales que no captura el HA. El uso de redes NAR más complejas (estructura más compleja, mayor número de neuronas y mayores retardos) no necesariamente mejora el desempeño predictivo, por lo que es necesario evaluar diferentes configuraciones para encontrar el más apropiado. El entrenamiento es un proceso clave y la repleción es necesaria para encontrar una configuración adecuada. Ambos métodos muestran un buen desempeño y tienen ventajas y desventajas. Por tanto, concluimos que el uso conjunto de ambos métodos, aprovechando las mejores características de cada una, podría conducir a una estrategia más robusta para predecir las elevaciones del nivel del mar en el estero de Urías y otras lagunas costeras tropicales.

\section{Agradecimientos}

JGCM y EMMR recibieron apoyo del Consejo Nacional de Ciencia y Tecnología (CONACYT, México) mediante una beca postdoctoral. Los siguientes proyectos brindaron financiamiento parcial: CONACYT 108093, CB2010/153492 y INFR-2013-01 204818; PAPIIT-DGAPA IN203313 y IB201612; y SEP PROMEP/103.5/12/4812. Las simulaciones se realizaron en la supercomputadora Miztli de la Universidad Nacional Autónoma de México (Dirección General de Cómputo y de Tecnologías de Información y Comunicación). Se agradece a Germán Ramírez Reséndiz (manejo de datos), Onésimo López Ramos (registro de datos) y Paola Rodríguez Reynaga (corrección y edición del inglés).

Traducido al español por Christine Harris.

Carbajal N, Backhaus JO. 1998. Simulation of tides, residual flow and energy budget in the Gulf of California. Oceanol. Acta 21: 429-446. http://dx.doi.org/10.1016/S0399-1784(98)80028-5

Cardoso-Mohedano JG. 2013. Desarrollo de un modelo para el estudio de la dispersión de contaminantes provenientes de una granja de cultivo de camarón en el complejo lagunar estero de 
Urías: Una laguna costera urbanizada (México). $\mathrm{PhD}$ thesis, Universitat Politècnica de Catalunya, Spain, 145 pp.

Cooley JW, Tukey JW. 1965. An algorithm for the machine calculation of complex Fourier series. Math. Comp. 19: 297-301. http://dx.doi.org/10.1090/S0025-5718-1965-0178586-1

Costanza R, d'Arge R, de Groot R, Farber S, Grasso M, Hannon B, Limburg K, Naeem S, O’Neill RV, Paruelo J, Raskin RG, Sutton P, van den Belt M. 1997. The value of the world's ecosystem services and natural capital. Nature 387: 253-260. http://dx.doi.org/10.1038/387253a0

Filippo A, Rebelo-Torres AJ, Kjerfve B, Monat A. 2012. Application of artificial neural network (ANN) to improve forecasting of sea level. Ocean Coast. Manage. 55: 101-110. http://dx.doi.org/10.1016/j.ocecoaman.2011.09.007

Filloux JH. 1973. Tidal patterns and energy balance in the Gulf of California. Nature 243: 217-221. http://dx.doi.org/10.1038/243217a0

Foreman MGG, Henry RF. 1989. The harmonic analysis of tidal model time series. Adv. Water Resour. 12: 109-120. http://dx.doi.org/10.1016/0309-1708(89)90017-1

Haykin S. 1999. Neural Networks: A Comprehensive Foundation. 2nd ed. Prentice Hall, Upper Saddle River, New Jersey.

Hendershott MC, Speranza A. 1971. Co-oscillating tides in long, narrow bays: The Taylor problem revisited. Deep-Sea Res. Oceanogr. Abs. 18: 959-980. http://dx.doi.org/10.1016/0011-7471(71)90002-7

[INEGI] Instituto Nacional de Estadística y Geografía. 2013. México en Cifras. México [cited 1 September 2013]. Available from: http://www3.inegi.org.mx/sistemas/mexicocifras/

Lee TL. 2004. Back-propagation neural network for long-term tidal predictions. Ocean Eng. 31: 225-238. http://dx.doi.org/10.1016/S0029-8018(03)00115-X

Lee TL, Jeng DS. 2002. Application of artificial neural networks in tide-forecasting. Ocean Eng. 29: 1003-1022. http://dx.doi.org/10.1016/S0029-8018(01)00068-3

Leffler KE, Jay DA. 2009. Enhancing tidal harmonic analysis: Robust (hybrid L1/L2) solutions. Cont. Shelf Res. 29: 78-88. http://dx.doi.org/10.1016/j.csr.2008.04.011

Lin T, Horne BG, Tino P, Giles CL. 1996. Learning Long-Term Dependencies in NARX Recurrent Neural Networks. IEEE Trans. Neural Netw. 7 (6): 1329-38. http://dx.doi.org/10.1109/72.548162
Makarynskyy O, Makarynska D, Kuhn M, Featherstone WE. 2004. Predicting sea level variations with artificial neural networks at Hillarys Boat Harbour, Western Australia. Estuar. Coast. Shelf Sci. 61: 351-360. http://dx.doi.org/10.1016/j.ecss.2004.06.004

Montaño-Ley Y, Peraza-Vizcarra R, Páez-Osuna F. 2008. Tidal hydrodynamics and their implications for the dispersion of effluents in Mazatlán Harbor: An urbanized shallow coastal lagoon. Water Air Soil Pollut. 194: 343-357. http://dx.doi.org/10.1007/s11270-008-9721-0

Ochoa-Izaguirre MJ. 1999. Composición y distribución de macroalgas en el sistema lagunar de Urías (Mazatlán, Sinaloa, México): Variacion estacional de la biomasa en relación con la disponibilidad de nutrientes y algunos factores ambientales. MSc thesis, Universidad Nacional Autónoma de México (UNAM), 99 pp.

Ochoa-Izaguirre MJ, Soto-Jiménez MF. 2013. Evaluation of nitrogen sources in the Urías lagoon system, Gulf of California, based on stable isotopes in macroalgae. Cienc. Mar. 39: 413-430. http://dx.doi.org/10.7773/cm.v39i4.2285

Pawlowicz R, Beardsley B, Lentz S. 2002. Classical tidal harmonic analysis including error estimates in MATLAB using T_TIDE. Comput. Geosci. 28: 929-937. http://dx.doi.org/10.1016/S0098-3004(02)00013-4

Salas-Pérez JJ, Salas-Monreal D, Arenas-Fuentes VE, Salas-deLeón DA, Riveron-Enzastiga ML. 2008. Tidal characteristics in a coral reef system from the western Gulf of Mexico. Cienc. Mar. 34: 467-478. http://dx.doi.org/10.7773/cm.v34i4.1364

Shetti R, Dwarakish SG. 2013. Prediction of Tides Using Neural Networks at Karwar, West Coast of India. Development and Applications of Oceanic Engineering, Development and Applications of Oceanic Engineering 2 (3). http://www.daoe-journal.org/paperInfo.aspx?ID=5324

[UNDP] United Nations Development Programme. 2005. Human Development Report 2005: International cooperation at a crossroads: Aid, trade and security in an unequal world. New York [cited 1 september 2014]. Available from: http:// hdr.undp.org/en/content/human-development-report-2005

Received September 2014, accepted November 2014. 